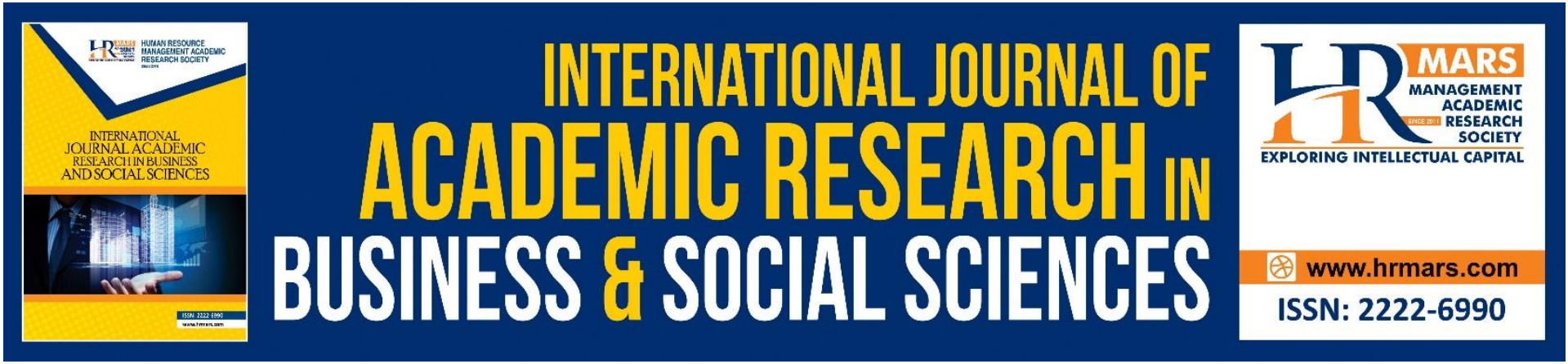

\title{
A Systematic Review for Supply Chain Integration and Risks
}

\section{Huang Duoming and Thoo Ai Chin}

To Link this Article: http://dx.doi.org/10.6007/IJARBSS/v12-i1/11856 DOI:10.6007/IJARBSS/v12-i1/11856

Received: 13 November 2021, Revised: 16 December 2021, Accepted: 26 December 2021

Published Online: 10 January 2022

In-Text Citation: (Duoming \& Chin, 2022)

To Cite this Article: Duoming, H., \& Chin, T. A. (2022). A Systematic Review for Supply Chain Integration and Risks. International Journal of Academic Research in Business and Social Sciences, 12(1), 715 - 729.

Copyright: (c) 2022 The Author(s)

Published by Human Resource Management Academic Research Society (www.hrmars.com)

This article is published under the Creative Commons Attribution (CC BY 4.0) license. Anyone may reproduce, distribute, translate and create derivative works of this article (for both commercial and non0-commercial purposes), subject to full attribution to the original publication and authors. The full terms of this license may be seen at: http://creativecommons.org/licences/by/4.0/legalcode

Vol. 12, No. 1, 2022, Pg. $715-729$

http://hrmars.com/index.php/pages/detail/IJARBSS

JOURNAL HOMEPAGE

Full Terms \& Conditions of access and use can be found at

http://hrmars.com/index.php/pages/detail/publication-ethics 


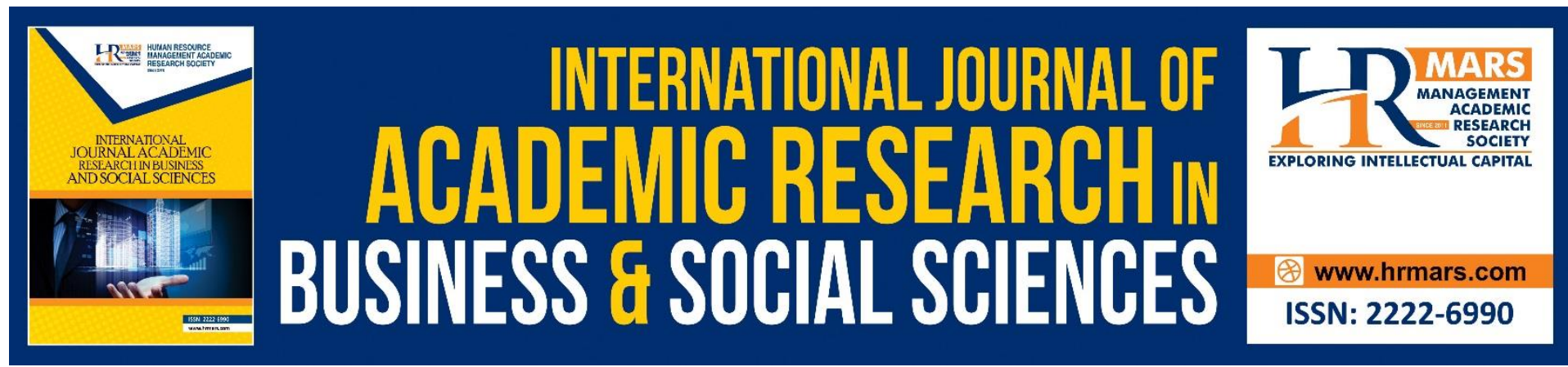

\title{
A Systematic Review for Supply Chain Integration and Risks
}

\author{
Huang Duoming ${ }^{1}$ and Dr. Thoo Ai Chin ${ }^{2}$ \\ ${ }^{1} \mathrm{PhD}$ Researcher, Azman Hashim International Business School, Universiti Teknologi \\ Malaysia, 81310 SKUDAI, Malaysia, ${ }^{2}$ Senior Lecturer, Azman Hashim International Business \\ School, Universiti Teknologi Malaysia, 81310 SKUDAl, Malaysia.
}

\begin{abstract}
In past decades, supply chain integration is used as a tool for manufacturers to earn competitiveness and improve performance. With the pace of globalization, the scope of the supply chain network has extended and increased the challenges for supply chain integration. This means the integrating processes have enhanced the vulnerability of a supply chain network. Recently, the integrated global supply chains are disrupted by disease outbreaks, natural disasters, and canal blocks. The risks embedded in the supply chain are catching the eyes of academicians and practitioners. Changes are expected after global supply chain disruptions concerning the size of the network, supplier locations, and network management, which are highly related to supply chain integration and supply chain risk management. Hence, this paper aims to investigate the dimensions of supply chain integration adapting to the changing world. Furthermore, this study adopts the systematic review approach to identify the dimensions of supply chain integration and construct a supply chain integration framework. The review found that supply chain integration dimensions including internal integration, supplier integration, customer integration, and service provider integration are important for practitioners. Ultimately, this review recommends future studies to focus on the impact of supply chain integration on supply chain risk management.
\end{abstract}

Keywords: Dimensions, Supply Chain Integration, Supply Chain Risk

\section{Introduction}

Nowadays, manufacturers are competing on the supply chain for providing quick delivery, innovative and customized products to satisfy customer needs. In addition, globalization and the development of technologies, especially information technology have changed the relationship structure of manufacturer and supply chain partners, which drives manufacturers to integrate internal functions and external partners. From the manufacturing industries' perspective, supply chain integration is a strategic and high-level inter-organizational collaboration between the focal manufacturing firm and supply chain partners, i.e., suppliers, distributors, retailers, and customers (Kang et al., 2018). In previous literature, supply chain integration is considered a way to improve the performance of supply chains. Increasing evidence indicates that supply chain integration positively impacts supply chain performance including cost, time, responsiveness, operation quality, and innovation (Kumar et al., 2020). 
However, the expansion of network and integration has brought additional dependency on supply chain stakeholders, both internal and external, to the companies, which increased the supply chain's vulnerability (Flynn et al., 2009). Recent examples like the COVID-19 pandemic and the 2021 Suez Canal obstruction have negatively affected the supply chain worldwide. Hence, supply chain safety is highly concerned after global supply chain disruptions involving the size of the network, supplier locations, and network management, which are highly related to supply chain integration. The ever-changing external environment puts forward new requirements for supply chain integration. A clear supply chain integration framework can provide an adequate basis for related research and practice. Therefore, this paper aims to investigate the dimensions of supply chain integration adapting to the changing world. To achieve this objective, the following research questions need to be addressed: (1) What dimensions of supply chain integration are recognized in prior studies? (2) How the supply chain integration dimensions impact the supply chain in coping with supply chain risk?

To address the research questions above, the current study aims to determine the dimensions of supply chain integration and its impact on supply chain risks. In addition, this paper also focuses on the relationship between supply chain integration and supply chain risk, and proposes future research directions. This paper systematically reviews research papers and proposes a dimensional framework of supply chain integration, which can provide a reference for assessing supply chain integration and supply chain risks.

\section{Concepts and Definitions \\ Supply Chain Integration}

The definition of supply chain integration was first introduced by Steven in 1989, taking the manufacturing industry as a research objective. From then on, in the past few decades, researchers have refined the definition of supply chain integration which refers to a strategic and high-level inter-organizational collaboration (e.g., information sharing, joint decision making, and system coupling) between the focal firm and supply chain partners, i.e., suppliers, distributors, retailers, and customers (Kang et al., 2018). By integrating material flow, information flow, and financial flow, and other resources (e.g., human resources and knowledge) with supply chain partners, the supply chain can provide end customers with high-value products (Wang et al., 2018). Furthermore, supply chain integration should concentrate on customer value-creating activities and overcome the no value-added processes. Therefore, the supply chain integration refers to the focal firm breaks the organization's internal functional barriers and strategically collaborates with external supply chain partners in order to provide high-value products to final customers.

\section{Supply Chain Integration Dimensions}

The dimensions of supply chain integration have been widely discussed in previous literature, and there are two main approaches to conceptualize supply chain integration. One is to ignore boundaries between and within organizations, focusing on strategies and operations that describes supply chain integration, and aims to make the supply chain participants into a unified entity and provides high-value products. Researchers stressed collaboration, information sharing, and joint decision-making are the fundamental components of the supply chain integration (Bruque-Cámara et al., 2016). For example, Angeles (2008) described supply chain integration as operations of integrating physical flow, information flow, and financial flow integration. Wang et al (2016) constructed a three-dimension framework, which involves strategic alliance, information sharing, and process coordination. 
Another approach considered two boundaries concerning the supply chain integration framework: internal integration and external integration. Scholars who supported this definition have conceptualized supply chain integration into three dimensions: internal integration, supplier integration, and customer integration (Boer and Boer, 2019). Furthermore, as globalization makes the geographical distribution of supply chain partners more dispersed, the logistics service provider becomes a critical supply chain practice component (Wang et al., 2020). Moreover, the physical distance and increasing demand for information sharing forcing the supply chain participants to invest more in information technology, such as enterprise resource planning, radio frequency identification, electronic data interchange, and so on (Oghazi et al., 2018). Therefore, some authors extended the supply chain integration beyond suppliers and customers and introduced partner integration, e.g., trade partners, logistics service providers, and information technology service providers (Perdana et al., 2019).

\section{Supply Chain Risk}

The definition of supply chain risk is described as an unexpected and abnormal situation, such as interruption of raw material supply, which leads to inefficiency operations, high cost, or disruptions of the supply chain (Baryannis et al., 2018). Taking a recent supply chain disruption as an example, according to the British Broadcasting Corporation's report, the 2021 Suez Canal obstruction has disrupted approximately 9.6 billion US dollars worth of goods every day (Harper, 2021). The Suez Canal is an important channel for the global energy and commodity supply chain, and the blockage of the Suez Canal has caused the world crude oil prices rose by $4 \%$ on the second day of the incident (Bodt et al., 2021; Lee and Wong, 2021).

Globalization and supply chain integration, especially external integration, has expanded the supply chain network and increased the supply chain's complexity. Global sourcing and international logistics lead the supply chain to take risks, implying that the global supply chain structure has become more vulnerable to risks with low supply chain performance (Munir et al., 2020).

\section{Methodology}

The literature review is a scientific methodology of research for aggregating and comprehending knowledge recorded (Khanuja and Jain, 2019). By systematically reviewing literature related to supply chain integration and supply chain risk, this study deals with reporting the review, which involves articles employing descriptive analysis, thematic classification, and reporting of the review results. This study only contains the papers published in English between 2000 and 2020 in the Emerald insight database. The review processes are shown in Table 1. 
Table 1: Review processes

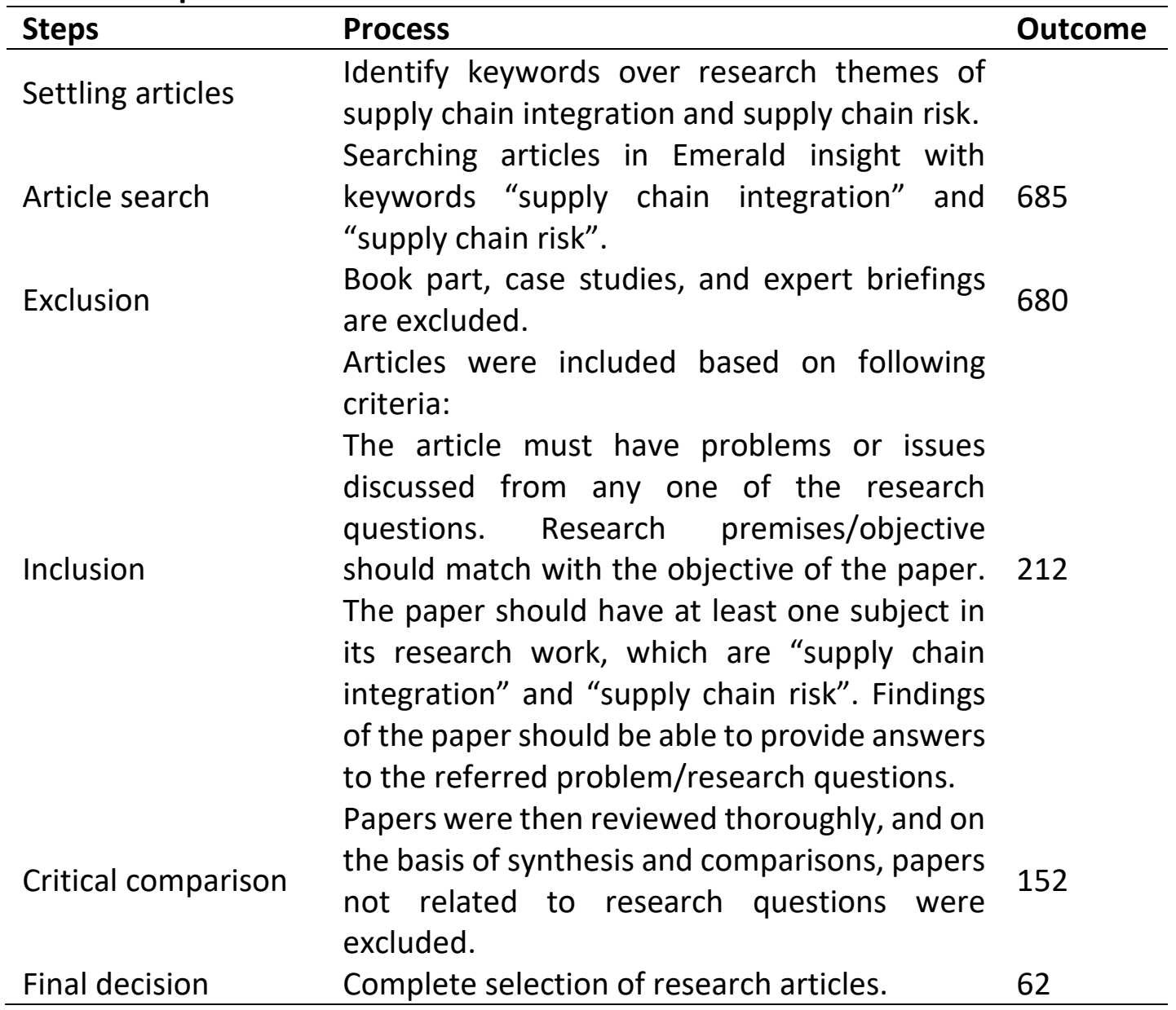

The current study explores the distribution of papers related to supply chain integration published between 2000 and 2020 in cited journals. Furthermore, this paper analyses the final selected articles and classifies them according to the adoption of supply chain integration dimensional framework. Summarizes the dimensional framework of supply chain integration, which can be used to provide help for future research. Finally, this study analyses the article that studies the impact of supply integration on supply chain risks, and summarizes the impact of supply chain integration on supply chain risks.

\section{Results}

\section{Classification of Journals and Publication Trend}

Analyse the source of the article and understand the journal's impact on the field of supply chain integration. As shown in Table 2, the 62 selected publications were published in 16 journals in the past decade. The top three journals cover $53 \%$ of publications. As shown in Fig.1, in 2006, Leavy (2006) and Wilding and Humphries (2006) published related articles. Between 2007 and 2013, researchers did not pay much attention. From 2014 to 2019, the number of articles fluctuated between 2 and 8 . The number of articles fluctuated between 2 to 8 in 2014-2019. The number of published articles subsequently increased rapidly, with 11 articles in 2020 and 10 in 2021 . The rapid growth of related research may be closely related to the epidemic of COVID-19 in 2019. 


\section{Table 2: Classification of journals}

\begin{tabular}{ll}
\hline List of journals & Count. \\
\hline Supply Chain Management: An International Journal & 14 \\
The International Journal of Logistics Management & 10 \\
Benchmarking: An International Journal & 9 \\
Industrial Management and Data Systems & 4 \\
International Journal of Operations and Production Management & 4 \\
Asia Pacific Journal of Marketing and Logistics & 3 \\
International Journal of Physical Distribution and Logistics Management & 2 \\
International Journal of Emerging Markets & 2 \\
Journal of Manufacturing Technology Management & 2 \\
Business Process Management Journal & 1 \\
Handbook of Business Strategy & 1 \\
International Journal of Energy Sector Management & 1 \\
International Journal of Pharmaceutical and Healthcare Marketing & 1 \\
Journal of Enterprise Information Management & 1 \\
Journal of Global Operations and Strategic Sourcing & 1 \\
Journal of Islamic Marketing & 1 \\
Journal of Knowledge Management & 1 \\
Journal of Enterprise Information Management & 1 \\
Journal of Business \& Industrial Marketing & 1 \\
Industrial Management \& Data Systems & 1 \\
International Journal of Productivity and Performance Management & 1 \\
Total & 62 \\
\hline
\end{tabular}

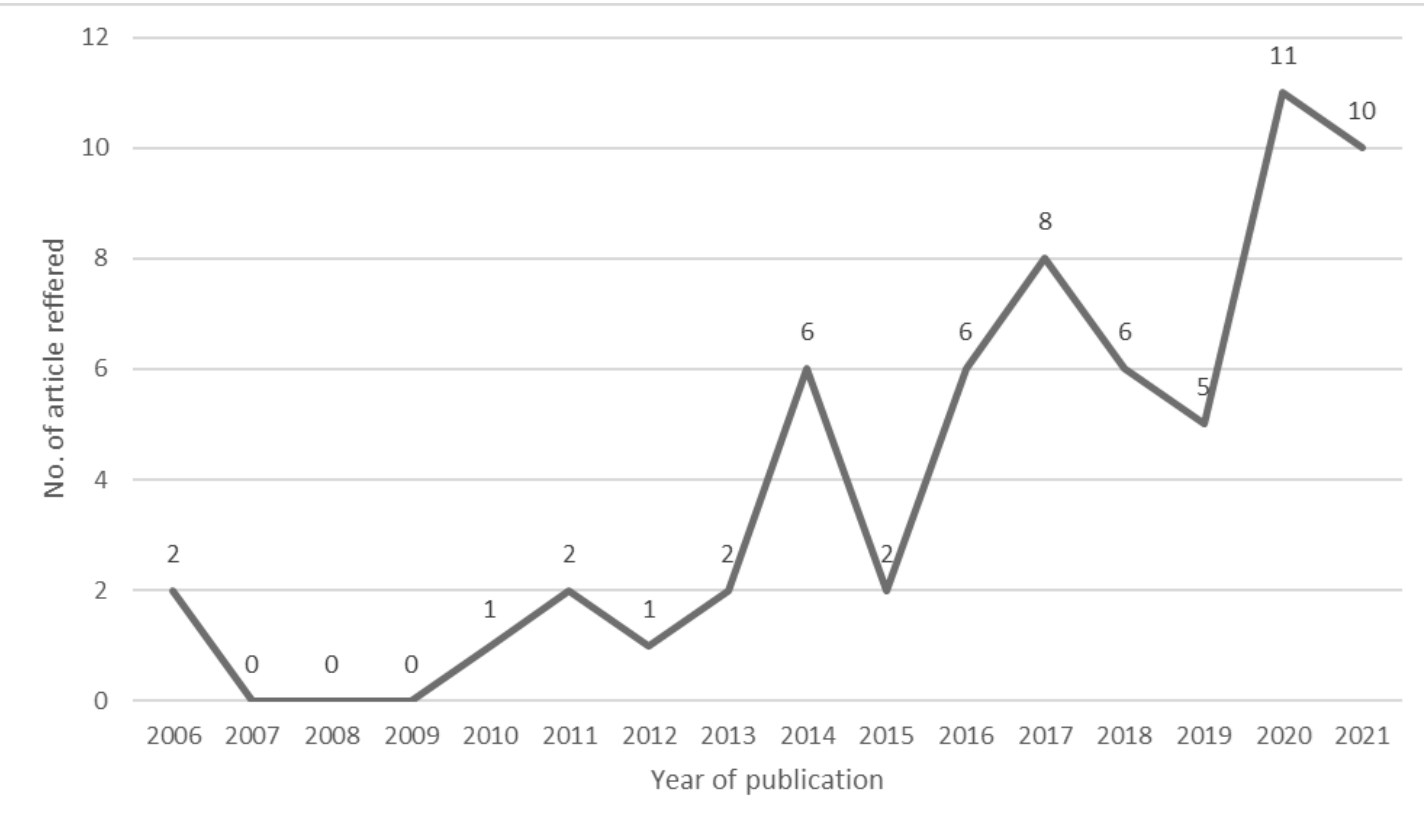

Figure 1: Publication trend

\section{Supply Chain Integration Dimensional Framework}

Both approaches mentioned in the previous text stress the critical role of information, material movement, and financial component in supply chain integration. As shown in Table 3, 8 articles in the reviewing pool adopted the unidimensional framework, which aimed to 
integrate all supply chain participants into one organization. For example, Panahifar et al (2018) investigated the impact of information-related factors on the collaboration among all supply chain partners following similar instructions. Such a situation is challenging to realize when supply chain partners are from different regions. As the whole network becomes a unified entity, the scale of the organization will sharply expand, which may also increase the rate of supply chain risk.

Table 3: Adoption of dimensional framework

\begin{tabular}{|c|c|c|}
\hline Dimensional framework & Authors & Count. \\
\hline Unidimensional & $\begin{array}{l}\text { T.S. and V. (2020); Panahifar et al } \\
\text { (2018); Haque and Islam (2018); } \\
\text { Tieman (2017); Pradabwong et al. } \\
\text { (2017); Zhang et al (2015); Kamal } \\
\text { and Irani (2014); Wilding and } \\
\text { Humphries (2006) }\end{array}$ & 8 \\
\hline Internal and external integration & $\begin{array}{l}\text { Li et al (2021); Piprani et al (2020); } \\
\text { Chaudhuri (2020); Azadegan (2020); } \\
\text { Kalyar et al (2019); Nguyen et al } \\
\text { (2019); Yu et al (2018); Polater and } \\
\text { Demirdogen (2018); Tarifa- } \\
\text { Fernandez and Burgos-Jiménez } \\
\text { (2017); Kumar and Singh (2017); } \\
\text { Riley et al (2016); Simangunsong et } \\
\text { al (2016); Sundram et al. (2016); } \\
\text { Meixell et al (2014); Sharma and } \\
\text { Bhat (2014); Guan and Rehme } \\
\text { (2012) }\end{array}$ & 16 \\
\hline $\begin{array}{l}\text { Internal, supplier, and customer } \\
\text { integration }\end{array}$ & $\begin{array}{l}\text { Kwamega et al (2019); Delic et al } \\
\text { (2019); Kanyoma et al (2018); } \\
\text { Turkulainen et al (2017); Abdallah et } \\
\text { al (2017); Cao et al (2015); Xu et al } \\
\text { (2014); Seo and Dinwoodie (2014); } \\
\text { Zhao et al (2013); Hong et al. (2010); } \\
\text { Danese and Romano (2013); } \\
\text { Chowdhury et al (2019); Shou et al } \\
\text { (2018); Martinez-Neri (2016); Kache } \\
\text { and Seuring (2014); Sundram et al. } \\
\text { (2011); Abdallah et al (2021); Afshan } \\
\text { et al (2021); Kanyoma et al (2020); } \\
\text { Liu et al (2021); Ramos et al (2021); } \\
\text { Shukor et al (2020); Tian et al (2021); } \\
\text { Sreedevi et al (2021) }\end{array}$ & 24 \\
\hline Internal and supplier integration & $\begin{array}{l}\text { Leavy (2006); Tse et al (2011); } \\
\text { Dhaigude et al (2021) }\end{array}$ & 3 \\
\hline $\begin{array}{l}\text { Internal, supplier, customer and } \\
\text { information integration }\end{array}$ & Nayal et al (2021) & 1 \\
\hline
\end{tabular}




\begin{tabular}{|c|c|c|}
\hline $\begin{array}{l}\text { Cross-functional and external } \\
\text { integration }\end{array}$ & Poberschnigg et al (2020) & 1 \\
\hline $\begin{array}{l}\text { Cross-functional, demand and } \\
\text { supply integration }\end{array}$ & Freitas et al (2020) & 1 \\
\hline $\begin{array}{l}\text { Cross-functional, manufacturing } \\
\text { network, and external integration }\end{array}$ & Hu et al (2019) & 1 \\
\hline $\begin{array}{l}\text { Information, operation and } \\
\text { relational integration }\end{array}$ & Zhu et al (2017) & 1 \\
\hline $\begin{array}{l}\text { Information, operation and new } \\
\text { product development integration }\end{array}$ & Ramirez et al (2020) & 1 \\
\hline $\begin{array}{l}\text { Information integration, process } \\
\text { integration or vertical integration }\end{array}$ & Sabet et al (2017) & 1 \\
\hline $\begin{array}{l}\text { Management information systems, } \\
\text { inventory management and supply } \\
\text { chain relationships }\end{array}$ & Tse et al (2016) & 1 \\
\hline $\begin{array}{l}\text { Strategic alliance, information } \\
\text { sharing, and process coordination }\end{array}$ & Wang et al (2018) & 1 \\
\hline $\begin{array}{l}\text { Upstream and downstream } \\
\text { integration }\end{array}$ & $\begin{array}{l}\text { Aljanabi and Ghafour (2020); Yu, } \\
\text { Huo, and Zhang (2021) }\end{array}$ & 2 \\
\hline Total & & 62 \\
\hline
\end{tabular}

In addition, as shown in Table 3, 39 articles used a dual (internal and external) or ternary (internal, supplier, and customer) framework in the study. At the same time, the crossfunctional integration proposed by Poberschnigg et al (2020) and Freitas et al. (2020) refers to the internal integration of focal firm to a certain extent. Therefore, this framework of internal integration and external integration is a definition accepted by more scholars.

It is worth noting that some scholars who have adopted the dual framework pointed out that external integration should not be limited to suppliers and customers. For example, Tarifa-Fernandez and Burgos-Jiménez (2017) proposed that external integration should consider the moderating effect of logistics capabilities on performance. Kumar and Singh (2017) emphasized that information and communication technology affects the performance of this supply chain integration. Thus, logistics service providers and information service providers should be adopted in the supply chain integration dimensional framework.

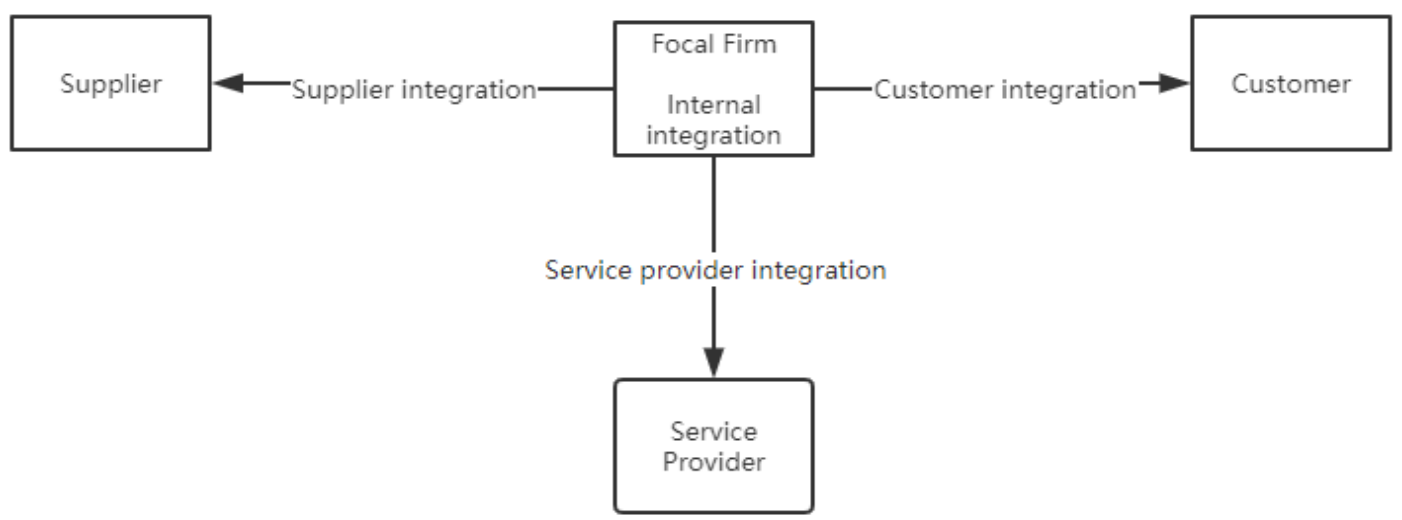

Figure 2. Supply chain integration dimensional framework 


\section{Impact of Supply Chain Integration on Supply Chain Risks}

Supply chain integration is considered a powerful weapon for supply chain managers to improve supply chain capacity. For example, Sabet et al (2017) pointed out that a high supply chain integration helps fast-growing industries cope with demand uncertainty. Riley et al (2016) suggested that internal integration enables managers to improve their ability to scan supply chain risks and identify them. Sreedevi et al (2021) emphasized that in the global supply chain, companies need to rely on many external resources to maintain operations. Therefore, effective external integration plays a vital role in mitigating supply chain risks. Thus, the supply chain integration improves the efficiency of information sharing among the supply chain partners, which may enhance the risk prediction ability of the supply chain. Moreover, joint decision-making and system coupling have the advantages of smooth supply chain processes, reducing the supply chain risk rate. Nayal et al (2021) pointed out that the information integration among supply chain participants enables real-time information sharing, which helps artificial intelligence to identify supply chain nodes' disruption risk factors.

Chaudhuri et al (2020) believes that when supply chain integration is used to develop capabilities for joint risk planning within the organization and with members of the broader supply network, and then to develop collaborative risk management capabilities, which may improve the supply chain's ability to respond to risks. However, the network characteristics produced by high-level supply chain integration harm the effectiveness of risk management. A possible explanation is that modern supply chain integration leads to a complex network system involving global supply chain stakeholders. As more participants from different countries joining the supply chain system, the supply chain potential risk has increased. For example, during the COVID-19 pandemic, the quarantine of Wuhan China resulted in a shortage of auto parts for Hyundai Motor Company, which eventually closed its South Korean factory (Chowdhury et al., 2019). Therefore, the impact of supply chain integration on the ability of the supply chain to respond to risks is still controversial. Further research needs to be established to determine the connection between them.

\section{Conclusions}

In past decades, supply chain integration has been widely discussed. Researchers tried to define supply chain integration and conceptualize the framework from different views. Most researchers believe supply chain integration enhances supply chain performance. In this context, the scope of supply chain network and integration expand rapidly, meanwhile, bring the vulnerability to supply chain system. In the past few years, natural disasters and humancaused accidents frequently have disrupted the integrated global supply chain and caused many economic losses. Especially, COVID-19 has exposed the lack of effective means to cope with changes in geopolitics or customer needs in the global supply chain (Free and Hecimovic, 2020). Therefore, conceptualize a supply chain integration dimensional framework in the context of changeable natural, economic and political environment is necessary.

In this investigation, the aim is to identify the dimensions of supply chain integration and assess the impact of supply chain integration on supply chain risk, which should provide a systemic view of adopting supply chain integration in supply chain management practice. Practitioners need to balance the risk while integrating with supply chain partners. Furthermore, the present study focuses on conceptualizing a supply chain integration structure which may contribute to further study of the impact of supply chain integration on supply chain risk management. The main contribution of this research is embodied in the 
definition of the framework of supply chain integration through literature review, which can provide researchers with references for future research. At the same time, practitioners can use the framework of supply chain integration to provide ideas for implementing supply chain integration.

\section{References}

Abdallah, A. B., Abdullah, M. I., \& Mahmoud Saleh, F. I. (2017). The effect of trust with suppliers on hospital supply chain performance. Benchmarking: An International Journal, 24(3), 694-715. https://doi.org/10.1108/bij-05-2016-0062

Abdallah, A. B., Rawadiah, O. M., Al-Byati, W., \& Alhyari, S. (2021). Supply chain integration and export performance: the mediating role of supply chain performance. International Journal of Productivity and Performance Management, ahead-of-print(ahead-of-print). https://doi.org/10.1108/ijppm-02-2021-0076

Afshan, N., Mandal, P., Gunasekaran, A., \& Motwani, J. (2021). Mediating role of immediate performance outcomes between supply chain integration and firm performance. Asia Pacific Journal of Marketing and Logistics, ahead-of-print(ahead-of-print). https://doi.org/10.1108/apjml-11-2020-0841

Aljanabi, A. R. A., \& Ghafour, K. M. (2020). Supply chain management and market responsiveness: a simulation study. Journal of Business \& Industrial Marketing, aheadof-print(ahead-of-print). https://doi.org/10.1108/jbim-12-2019-0514

Angeles, R. (2008). Anticipated IT infrastructure and supply chain integration capabilities for RFID and their associated deployment outcomes. Proceedings of the 10th International Conference on Information Integration and Web-Based Applications \& Services - liWAS '08. https://doi.org/10.1145/1497308.1497429

Azadegan, A., Syed, T. A., Blome, C., \& Tajeddini, K. (2020). Supply chain involvement in business continuity management: effects on reputational and operational damage containment from supply chain disruptions. Supply Chain Management: An International Journal, ahead-of-print(ahead-of-print). https://doi.org/10.1108/scm-082019-0304

Baryannis, G., Validi, S., Dani, S., \& Antoniou, G. (2018). Supply chain risk management and artificial intelligence: state of the art and future research directions. International Journal of Production Research, 57(7), 1-24.

https://doi.org/10.1080/00207543.2018.1530476

Bodt, E. de, Cousin, J.-G., \& Dupire-Declerck, M. (2021). The CSR Supply Chain Risk Management Hypothesis Evidence from the Suez Canal Ever Given Obstruction. SSRN Electronic Journal. https://doi.org/10.2139/ssrn.3867169

Boer, H., \& Boer, H. (2019). Design-for-variety and operational performance. Journal of Manufacturing Technology Management, 30(2), 438-461. https://doi.org/10.1108/jmtm-03-2018-0065

Bruque-Cámara, S., Moyano-Fuentes, J., \& Maqueira-Marín, J. M. (2016). Supply chain integration through community cloud: Effects on operational performance. Journal of Purchasing and Supply Management, 22(2), 141-153.

https://doi.org/10.1016/j.pursup.2016.04.003

Cao, Z., Huo, B., Li, Y., \& Zhao, X. (2015). Competition and supply chain integration: a taxonomy perspective. Industrial Management \& Data Systems, 115(5), 923-950. https://doi.org/10.1108/imds-10-2014-0315 
Chaudhuri, A., Ghadge, A., Gaudenzi, B., \& Dani, S. (2020). A conceptual framework for improving effectiveness of risk management in supply networks. International Journal of Logistics Management, The, 31(1), 77-98. https://doi.org/10.1108/ijlm-11-20180289

Chowdhury, P., Lau, K. H., \& Pittayachawan, S. (2019). Operational supply risk mitigation of SME and its impact on operational performance. International Journal of Operations \& Production Management, 39(4), 478-502. https://doi.org/10.1108/ijopm-09-20170561

Danese, P., \& Romano, P. (2013). The moderating role of supply network structure on the customer integration-efficiency relationship. International Journal of Operations \& Production Management, 33(4), 372-393. https://doi.org/10.1108/01443571311307226

Delic, M., Eyers, D. R., \& Mikulic, J. (2019). Additive manufacturing: empirical evidence for supply chain integration and performance from the automotive industry. Supply Chain Management: An International Journal. https://doi.org/10.1108/scm-12-2017-0406

Dhaigude, A. S., Kapoor, R., Gupta, N., \& Padhi, S. S. (2021). Linking supply chain integration to supply chain orientation and performance - a knowledge integration perspective from Indian manufacturing industries. Journal of Knowledge Management, ahead-ofprint(ahead-of-print). https://doi.org/10.1108/jkm-01-2020-0064

Flynn, B. B., Huo, B., \& Zhao, X. (2009). The impact of supply chain integration on performance: A contingency and configuration approach. Journal of Operations Management, 28(1), 58-71. https://doi.org/10.1016/j.jom.2009.06.001

Free, C., \& Hecimovic, A. (2020). Global supply chains after COVID-19: the end of the road for neoliberal globalisation? Accounting, Auditing \& Accountability Journal, ahead-ofprint(ahead-of-print). https://doi.org/10.1108/aaaj-06-2020-4634

Freitas, M. R. de, Pimenta, M. L., Hilletofth, P., Jugend, D., \& Oprime, P. C. (2020). Demand management: the role of cross-functional integration in a context of political turbulence. Asia Pacific Journal of Marketing and Logistics, 32(3), 817-839. https://doi.org/10.1108/apjml-11-2018-0473

Guan, W., \& Rehme, J. (2012). Vertical integration in supply chains: driving forces and consequences for a manufacturer's downstream integration. Supply Chain Management: An International Journal, 17(2), 187-201. https://doi.org/10.1108/13598541211212915

Haque, M., \& Islam, R. (2018). Impact of supply chain collaboration and knowledge sharing on organizational outcomes in pharmaceutical industry of Bangladesh. Journal of Global Operations and Strategic Sourcing, 11(3), 301-320. https://doi.org/10.1108/jgoss-022018-0007

Harper, J. (2021). Suez blockage is holding up $\$ 9.6 \mathrm{bn}$ of goods a day. BBC News. https://www.bbc.com/news/business-56533250

Hong, P., Tran, O., \& Park, K. (2010). Electronic commerce applications for supply chain integration and competitive capabilities. Benchmarking: An International Journal, 17(4), 539-560. https://doi.org/10.1108/14635771011060585

$\mathrm{Hu}$, W., Shou, Y., Kang, M., \& Park, Y. (2019). Risk management of manufacturing multinational corporations: the moderating effects of international asset dispersion and supply chain integration. Supply Chain Management: An International Journal, aheadof-print(ahead-of-print). https://doi.org/10.1108/scm-01-2019-0009 
Kache, F., \& Seuring, S. (2014). Linking collaboration and integration to risk and performance in supply chains via a review of literature reviews. Supply Chain Management: An International Journal, 19(5/6), 664-682. https://doi.org/10.1108/scm-12-2013-0478

Kalyar, M. N., Shafique, I., \& Ahmad, B. (2019). Effect of innovativeness on supply chain integration and performance. International Journal of Emerging Markets, 15(2), 362386. https://doi.org/10.1108/ijoem-09-2018-0486

Kamal, M. M., \& Irani, Z. (2014). Analysing supply chain integration through a systematic literature review: a normative perspective. Supply Chain Management: An International Journal, 19(5/6), 523-557. https://doi.org/10.1108/scm-12-2013-0491

Kang, M., Park, K., Yang, M. G. (Mark), \& Haney, M. H. (2018). Supply chain integration and coordination for international sourcing in the context of China's processing trade. Industrial Management \& Data Systems, 118(9), 1730-1748. https://doi.org/10.1108/imds-11-2017-0528

Kanyoma, K. E., Agbola, F. W., \& Oloruntoba, R. (2018). An evaluation of supply chain integration across multi-tier supply chains of manufacturing-based SMEs in Malawi. The International Journal of Logistics Management, 29(3), 1001-1024. https://doi.org/10.1108/ijlm-10-2017-0277

Kanyoma, K. E., Agbola, F. W., \& Oloruntoba, R. (2020a). Inhibitors and enablers of supply chain integration across multiple supply chain tiers: evidence from Malawi. The International Journal of Logistics Management, 32(2), 618-649. https://doi.org/10.1108/ijlm-06-2019-0161

Kanyoma, K. E., Agbola, F. W., \& Oloruntoba, R. (2020b). Inhibitors and enablers of supply chain integration across multiple supply chain tiers: evidence from Malawi. The International Journal of Logistics Management, 32(2), 618-649. https://doi.org/10.1108/ijlm-06-2019-0161

Khanuja, A., \& Jain, R. K. (2019). Supply chain integration: a review of enablers, dimensions and performance. Benchmarking: An International Journal, 27(1), 264-301. https://doi.org/10.1108/bij-07-2018-0217

Kumar, R., \& Kumar Singh, R. (2017). Coordination and responsiveness issues in SME supply chains: a review. Benchmarking: An International Journal, 24(3), 635-650. https://doi.org/10.1108/bij-03-2016-0041

Kumar, V., Jabarzadeh, Y., Jeihouni, P., \& Garza-Reyes, J. A. (2020). Learning orientation and innovation performance: the mediating role of operations strategy and supply chain integration. Supply Chain Management: An International Journal, ahead-ofprint(ahead-of-print). https://doi.org/10.1108/scm-05-2019-0209

Kwamega, M., Li, D., \& Abrokwah, E. (2019). Empirical analysis of integration practices among agribusiness firms. Business Process Management Journal. https://doi.org/10.1108/bpmj-08-2018-0220

Leavy, B. (2006). Supply chain effectiveness: strategy and integration. Handbook of Business Strategy, 7(1), 331-336. https://doi.org/10.1108/10775730610619025

Lee, J. M., \& Wong, E. Y. (2021). Suez Canal blockage: an analysis of legal impact, risks and liabilities to the global supply chain. MATEC Web of Conferences, 339, 01019. https://doi.org/10.1051/matecconf/202133901019

Li, Q., Yan, R., Zhang, L., \& Yan, B. (2021). Empirical study on improving international dry port competitiveness based on logistics supply chain integration: evidence from China. The International Journal of Logistics Management, ahead-of-print(ahead-of-print). https://doi.org/10.1108/ijlm-06-2020-0256 
Liu, S., Tan, J., Mao, H., \& Gong, Y. (2021). Does national culture matter? Understanding the impact of supply chain integration in multiple countries. Supply Chain Management: An International Journal, ahead-of-print(ahead-of-print). https://doi.org/10.1108/scm-03-2020-0099

Martinez-Neri, I. F. (2016). Supply chain integration opportunities for the offshore wind industry. International Journal of Energy Sector Management, 10(2), 191-220. https://doi.org/10.1108/ijesm-04-2015-0007

Meixell, M. J., Kenyon, G. N., \& Westfall, P. (2014). The effects of production outsourcing on factory cost performance: an empirical study. Journal of Manufacturing Technology Management, 25(6), 750-774. https://doi.org/10.1108/jmtm-10-2011-0099

Munir, M., Jajja, M. S. S., Chatha, K. A., \& Farooq, S. (2020). Supply chain risk management and operational performance: The enabling role of supply chain integration. International Journal of Production Economics, 227, 107667.

https://doi.org/10.1016/j.ijpe.2020.107667

Nayal, K., Raut, R., Priyadarshinee, P., Narkhede, B. E., Kazancoglu, Y., \& Narwane, V. (2021). Exploring the role of artificial intelligence in managing agricultural supply chain risk to counter the impacts of the COVID-19 pandemic. The International Journal of Logistics Management, ahead-of-print(ahead-of-print). https://doi.org/10.1108/ijlm-12-20200493

Nguyen, T. M. A., Hui, L., Khoa, V. D., \& Mehmood, S. (2019). Relational capital and supply chain collaboration for radical and incremental innovation. Asia Pacific Journal of Marketing and Logistics, 31(4), 1076-1094. https://doi.org/10.1108/apjml-10-20180423

Oghazi, P., Fakhrai Rad, F., Karlsson, S., \& Haftor, D. (2018). RFID and ERP systems in supply chain management. European Journal of Management and Business Economics, 27(2), 171-182. https://doi.org/10.1108/ejmbe-02-2018-0031

Panahifar, F., Byrne, P. J., Salam, M. A., \& Heavey, C. (2018). Supply chain collaboration and firm's performance. Journal of Enterprise Information Management, 31(3), 358-379. https://doi.org/10.1108/jeim-08-2017-0114

Perdana, Y. R., Ciptono, W. S., \& Setiawan, K. (2019). Broad span of supply chain integration: theory development. International Journal of Retail \& Distribution Management, 47(2), 186-201. https://doi.org/10.1108/ijrdm-03-2018-0046

Piprani, A. Z., Jaafar, N. I., \& Mohezar Ali, S. (2020). Prioritizing resilient capability factors of dealing with supply chain disruptions: an analytical hierarchy process (AHP) application in the textile industry. Benchmarking: An International Journal, 27(9), 2537-2563. https://doi.org/10.1108/bij-03-2019-0111

Poberschnigg, T. F. da S., Pimenta, M. L., \& Hilletofth, P. (2020). How can cross-functional integration support the development of resilience capabilities? The case of collaboration in the automotive industry. Supply Chain Management: An International Journal, 25(6), 789-801. https://doi.org/10.1108/scm-10-2019-0390

Polater, A., \& Demirdogen, O. (2018). An investigation of healthcare supply chain management and patient responsiveness. International Journal of Pharmaceutical and Healthcare Marketing, 12(3), 325-347. https://doi.org/10.1108/ijphm-07-2017-0040

Pradabwong, J., Braziotis, C., Tannock, J. D. T., \& Pawar, K. S. (2017). Business process management and supply chain collaboration: effects on performance and competitiveness. Supply Chain Management: An International Journal, 22(2), 107-121. https://doi.org/10.1108/scm-01-2017-0008 
Ramirez, M. J., Roman, I. E., Ramos, E., \& Patrucco, A. S. (2020). The value of supply chain integration in the Latin American agri-food industry: trust, commitment and performance outcomes. The International Journal of Logistics Management, 32(1), 281301. https://doi.org/10.1108/ijlm-02-2020-0097

Ramos, E., Patrucco, A. S., \& Chavez, M. (2021). Dynamic capabilities in the "new normal": a study of organizational flexibility, integration and agility in the Peruvian coffee supply chain. Supply Chain Management: An International Journal, ahead-of-print(ahead-ofprint). https://doi.org/10.1108/scm-12-2020-0620

Riley, J. M., Klein, R., Miller, J., \& Sridharan, V. (2016). How internal integration, information sharing, and training affect supply chain risk management capabilities. International Journal of Physical Distribution \& Logistics Management, 46(10), 953-980. https://doi.org/10.1108/ijpdlm-10-2015-0246

Sabet, E., Yazdani, N., \& De Leeuw, S. (2017). Supply chain integration strategies in fast evolving industries. The International Journal of Logistics Management, 28(1), 29-46. https://doi.org/10.1108/ijlm-01-2015-0013

Seo, Y.-J., Dinwoodie, J., \& Kwak, D.-W. (2014). The impact of innovativeness on supply chain performance: is supply chain integration a missing link? Supply Chain Management: An International Journal, 19(5/6), 733-746. https://doi.org/10.1108/scm-02-2014-0058

Sharma, S. K., \& Bhat, A. (2014). Supply chain risk management dimensions in Indian automobile industry. Benchmarking: An International Journal, 21(6), 1023-1040. https://doi.org/10.1108/bij-02-2013-0023

Shou, Y., Hu, W., Kang, M., Li, Y., \& Park, Y. W. (2018). Risk management and firm performance: the moderating role of supplier integration. Industrial Management \& Data Systems, 118(7), 1327-1344. https://doi.org/10.1108/imds-09-2017-0427

Shukor, A. A. A., Newaz, Md. S., Rahman, M. K., \& Taha, A. Z. (2020). Supply chain integration and its impact on supply chain agility and organizational flexibility in manufacturing firms. International Journal of Emerging Markets, ahead-of-print(ahead-of-print). https://doi.org/10.1108/ijoem-04-2020-0418

Simangunsong, E., Hendry, L. C., \& Stevenson, M. (2016). Managing supply chain uncertainty with emerging ethical issues. International Journal of Operations \& Production Management, 36(10), 1272-1307. https://doi.org/10.1108/ijopm-12-2014-0599

Sreedevi, R., Saranga, H., \& Gouda, S. K. (2021). Impact of a country's logistical capabilities on supply chain risk. Supply Chain Management: An International Journal, ahead-ofprint(ahead-of-print). https://doi.org/10.1108/scm-09-2020-0504

Sundram, V. P. K., Chandran, V., \& Awais Bhatti, M. (2016). Supply chain practices and performance: the indirect effects of supply chain integration. Benchmarking: An International Journal, 23(6), 1445-1471. https://doi.org/10.1108/bij-03-2015-0023

Sundram, V. P. K., Razak Ibrahim, A., \& Chandran Govindaraju, V. G. R. (2011). Supply chain management practices in the electronics industry in Malaysia. Benchmarking: An International Journal, 18(6), 834-855. https://doi.org/10.1108/14635771111180725

Tarifa-Fernandez, J., \& De Burgos-Jiménez, J. (2017). Supply chain integration and performance relationship: a moderating effects review. The International Journal of Logistics Management, 28(4), 1243-1271. https://doi.org/10.1108/ijlm-02-2016-0043

Tian, M., Huo, B., Park, Y., \& Kang, M. (2021). Enablers of supply chain integration: a technology-organization-environment view. Industrial Management \& Data Systems, ahead-of-print(ahead-of-print). https://doi.org/10.1108/imds-09-2020-0564 
Tieman, M. (2017). Halal risk management: combining robustness and resilience. Journal of Islamic Marketing, 8(3), 461-475. https://doi.org/10.1108/jima-06-2015-0041

TS, D., \& V, R. (2020). An integrated ANP-QFD approach for prioritization of customer and design requirements for digitalization in an electronic supply chain. Benchmarking: An International Journal, 28(4), 1213-1246. https://doi.org/10.1108/bij-06-2020-0298

Tse, Y. K., Hua Tan, K., Ho Chung, S., \& Kim Lim, M. (2011). Quality risk in global supply network. Journal of Manufacturing Technology Management, 22(8), 1002-1013. https://doi.org/10.1108/17410381111177458

Tse, Y. K., Zhang, M., Akhtar, P., \& MacBryde, J. (2016). Embracing supply chain agility: an investigation in the electronics industry. Supply Chain Management: An International Journal, 21(1), 140-156. https://doi.org/10.1108/scm-06-2015-0237

Turkulainen, V., Kauppi, K., \& Nermes, E. (2017). Institutional explanations. International Journal of Operations \& Production Management, 37(8), 1117-1140. https://doi.org/10.1108/ijopm-10-2015-0608

Wang, B., Childerhouse, P., Kang, Y., Huo, B., \& Mathrani, S. (2016). Enablers of supply chain integration. Industrial Management \& Data Systems, 116(4), 838-855. https://doi.org/10.1108/imds-09-2015-0403

Wang, B., Kang, Y., Childerhouse, P., \& Huo, B. (2018). Service supply chain integration: the role of interpersonal relationships. Industrial Management \& Data Systems, 118(4), 828-849. https://doi.org/10.1108/imds-02-2017-0062

Wang, Q., Huo, B., \& Zhao, X. (2020). What Makes Logistics Integration More Effective? Governance from Contractual and Relational Perspectives. Journal of Business Logistics, 41(3), 259-281. https://doi.org/10.1111/jbl.12236

Wilding, R., \& Humphries, A. S. (2006). Understanding collaborative supply chain relationships through the application of the Williamson organisational failure framework. International Journal of Physical Distribution \& Logistics Management, 36(4), 309-329. https://doi.org/10.1108/09600030610672064

Xu, D., Huo, B., \& Sun, L. (2014). Relationships between intra-organizational resources, supply chain integration and business performance. Industrial Management \& Data Systems, 114(8), 1186-1206. https://doi.org/10.1108/imds-05-2014-0156

Yu, K., Luo, B. N., Feng, X., \& Liu, J. (2018). Supply chain information integration, flexibility, and operational performance. The International Journal of Logistics Management, 29(1), 340-364. https://doi.org/10.1108/ijlm-08-2016-0185

Yu, Y., Huo, B., \& Zhang, Z. (Justin). (2021). Impact of information technology on supply chain integration and company performance: evidence from cross-border e-commerce companies in China. Journal of Enterprise Information Management, 34(1), 460-489. https://doi.org/10.1108/jeim-03-2020-0101

Zhang, C., Gunasekaran, A., \& Wang, W. Y. C. (2015). A comprehensive model for supply chain integration. Benchmarking: An International Journal, 22(6), 1141-1157. https://doi.org/10.1108/bij-05-2013-0060

Zhao, L., Huo, B., Sun, L., \& Zhao, X. (2013). The impact of supply chain risk on supply chain integration and company performance: a global investigation. Supply Chain Management: An International Journal, 18(2), 115-131. https://doi.org/10.1108/13598541311318773

Zhu, Q., Krikke, H., \& Caniëls, M. C. J. (2017). Integrated supply chain risk management: a systematic review. The International Journal of Logistics Management, 28(4), 11231141. https://doi.org/10.1108/ijlm-09-2016-0206 